\title{
Faktor Kesulitan Guru Dalam Proses Pembelajaran Di Ditinjau Dari Pengunaan Kurikulum, Struktur Materi, Sarana Dan Prasarana, Dan Alokasi Waktu
}

\author{
$\operatorname{Kadariah}^{1 *}$, Kusmaladewi ${ }^{2}$, Hasmiah $^{3}$ \\ 1,2,3 Manajemen Pendidikan Universitas Terbuka, Makassar \\ ${ }^{1}$ Email: kadariah@ecampus.ut.ac.id, ${ }^{2}$ Email: kusmaladewi@ecampus.ut.ac.id, \\ ${ }^{3}$ Email: hasmiah@ecampus.ut.ac.id \\ *Corresponding Author
}

\begin{abstract}
This study aims to find a picture of the difficulties experienced by teachers in the implementation of learning activities and the steps taken to overcome the difficulties encountered in learning. The research approach uses descriptive qualitative research to explain the phenomena of difficulties experienced by teachers in carrying out learning activities and steps taken to overcome difficulties encountered in learning. The data collection techniques used in this study were open questionnaires as primary data sources and observations. Data analysis uses descriptive statistics, to obtain a picture of the difficulty factors and the steps in implementing learning. The results showed that the implementation of the curriculum for learning activities and in formulating basic competencies were still the difficulties of subject teachers. The structure of the material in the learning curriculum is still an obstacle for the teacher because the material is not in accordance with the level of student ability. The availability of facilities and infrastructure as well as the allocation of time still need to be a major concern in improving the quality of learning
\end{abstract}

Keywords: Teacher Difficulty Factors; Teaching and Learning Process; Quality of Learning

\begin{abstract}
Abstrak. Penelitian ini bertujuan untuk mengetahui gambaran tentang kesulitan yang dialami oleh guru dalam pelaksanaan kegiatan pembelajaran dan langkah-langkah yang ditempuh untuk mengatasi kesulitan yang dihadapi dalam pembelajaran. Pendekatan penelitian menggunakan penelitian kualitatif yang bersifat deskriptif untuk menjelaskan fenomena kesulitan yang dialami guru dalam melaksanakan kegiatan pembelajaran dan langkah yang ditempuh untuk mengatasi kesulitan yang dihadapi dalam pembelajaran. Adapun teknik pengumpulan data dalam penelitian ini digunakan angket terbuka sebagai sumber data primer dan observasi. Analisis data menggunakan statistik deskriptif, untuk memperoleh gambaran tentang faktor kesulitan dan langkah pelaksanaan pembelajaran. Hasil penelitian menunjukkan bahwa pelaksanaan kurikulum untuk kegiatan pembelajaran dan dalam merumuskan kompetensi dasar masih merupakan kesulitan guru mata pelajaran. Struktur materi yang ada dalam kurikulum pembelajaran masih merupakan hambatan bagi guru karena materi yang ada masih belum sesuai dengan tingkat kemampuan siswa. Ketersediaan sarana dan prasarana serta alokasi waktu masih perlu menajdi perhatian utama dalam meningkatkan kualiatas pembelajaran.
\end{abstract}

Kata Kunci: Faktor Kesulitan Guru; Proses Pembelajaran; Kualitas Pembelajaran

\section{PENDAHULUAN}

Pendidikan di sekolah tidak terlepas dari kegiatan pembelajaran. Kegiatan pembelajaran merupakan hal pokok dalam proses pendidikan. Tercapai atau tidaknya suatu tujuan pendidikan salah satunya dipengaruhi oleh proses belajar yang dialami oleh siswa.

Dengan demikian, pendidikan nasional akan mampu mewujudkan manusia-manusia pembangunan yang dapat membangun dirinya sendiri serta bersama-sama bertanggung jawab atas pembangunan bangsa dalam mewujudkan kemakmuran. Kemakmuran menjadi tujuan sentral dalam kehidupan manusia jika ditinjau dari aspek ekonomi (Rahmatullah \& Inanna, 2017). Esensi tujuan pendidikan adalah pembentukan manusia yang bukan hanya dapat menyesuaikan diri hidup di dalam masyarakatnya, melainkan diri itu mampu menyumbangkan bagi penyempurnaan masyarakat itu sendiri. Hal ini kerena aktifitas atau perilaku ekonomi yang dilakukan manusia merupakan cerminan dari pengetahuan dan pemahaman berekonomi yang telah diperoleh 
melalui proses pembelajaran (Rahmatullah, 2018).

Perubahan-perubahan yang terjadi, terutama yang diakibatkan oleh perkembangan ilmu pengetahuan dan teknologi demikian pesatnya, sehingga bekal pendidikan yang diterima dari orang tua tidak akan memadai bagi anak-anak kita, sebab mereka harus menghadapi dunia yang pada hakekatnya berbeda apabila dibandingkan dengan keadaan sebelumnya. Untuk itu dibutuhkan sumber daya manusia dalam bidang pendidikan yang mampu merespon perkembangan ilmu pengetahuan dan teknologi terutama aplikasinya dalam proses pembelajaran (Ramli, Rahmatullah, Inanna, \& Dangnga, 2018).

Pendidikan merupakan proses budaya untuk meningkatkan harkat dan martabat manusia, dan pendidikan berlangsung seumur hidup dan dilaksanakan di dalam lingkungan keluarga, sekolah dan masyarakat. Karena itu pendidikan merupakan tanggung jawab bersama antara keluarga masyarakat dan pemerintah. Dalam lingkungan keluarga, pendidikan sebagai upaya untuk mempersiapkan anak menjadi menjadi generasi masa depan sesuai tuntutan perkembangan zaman (Inanna, Rahmatullah, Haeruddin, \& Marhawati, 2020).

Dalam upaya mencerdaskan kehidupan bangsa sebagaimana yang diamanatkan oleh Pembukaan Undang-Undang Dasar 1945. Pemerintah telah mengusahakan Sistem Pendidikan Nasional. Dalam sistem pendidikan nasional terkait cukup banyak komponen yang ikut mempengaruhi. Hal ini disebabkan karena pendidikan itu adalah merupakan sistem dimana melibatkan banyak komponen di dalamnya yang saling berkaitan antara komponen yang satu dengan komponen yang lainnya. Komponenkomponen itu diupayakan berjalan seoptimal mungkin sesuai dengan fungsinya masingmasing agar tujuan Pendidikan Nasional dapat tercapai.

Dalam Kurikulum 2013 guru memiliki peranan penting yaitu sebagai fasilitator. Namun, guru bukanlah satu-satunya sumber belajar, guru mendidik dan membimbing peserta didik agar kegiatan pendidikan terlaksana dengan baik, guru yang profesional tidak hanya cukup memenuhi persyaratan administratif, melainkan bagaimana guru dapat memberikan pengertian, pemahaman dan dapat mendorong peserta didik ke arah aktivitas secara individual terhadap ilmu yang diberikannya. Karena tuntutan sebagai guru dalam implementasi kurikulum seperti diatas itulah sangat wajar guru akan mengalami kesulitan. Hal ini di indikasikan bahwa guru kesulitan penerapan pembelajaran yang dirasakan sangat sulit karena kurangnya pelatihan dan pengetahuan yang dimiliki guru untuk menerapkan Kurikulum 2013 yang menggunakan pembelajaran saintifik pada proses pembelajarannya.

Sebagaimana di kemukakan, bahwa pemerintah telah melaksanakan berbagai upaya untuk meningkatkan hasil pendidikan agar upaya itu dapat terwujud, maka fungsi guru tetap memegang peranan penting dalam upaya menyikapi akan tugas dan tanggung jawabnya, baik sebagai pendidik maupun sebagai pengajar. Dalam kegiatan pembelajaran, guru berperan untuk membimbing anak didik mencapai tujuan pembelajaran, mengarahkan kegiatan pembelajaran dan siswa untuk menyelesaikan tugas-tugas yang diberikan (Rahmatullah \& Inanna, 2018).

Pendidikan diarahkan kepada pembentukan manusia yang didambakan sedangkan pengajaran adalah salah satu alat untuk membentuk manusia tersebut. Pendidikan bertujuan meningkatkan kualitas manusia yang mampu berdiri sendiri. Kalau konsep dasar ini dianalisa, maka guru selain sebagai warga negara juga merupakan agen pembaharuan yang memegang peranan sangat penting untuk mencapai tujuan tersebut.

Guru sebagai ujung tombak pendidikan kepadanya dituntut agar memiliki kemampuan yang diperlukan sebagai pendidik sekaligus pengajar. Dalam tugasnya sebagai pengajar, disamping guru harus menguasai materi dan metode yang digunakan paling tidak guru juga harus mampu menguasai perencanaan pengajaran dan terampil melaksanakannya.

Disamping kemampuan seperti dikemukakan di atas, juga seorang guru dituntut agar mampu melihat perkembanganperkembangan baru terhadap penanganan proses Pembelajaran. Dengan perkembangan baru yang dimaksud maka semakin dituntut pula akan kompetensi dari guru itu sendiri baik kompetensi yang berkenaan dengan kemampuan profesional kapasitas intelektual maupun edukasional dalam menunjang peningkatan kualitas proses Pembelajaran.

Proses Pembelajaran yang baik diharapkan dapat menghasilkan belajar yang baik, karena proses pendidikan secara keseluruhan dengan guru sebagai pemegang peranan utama. Dengan demikian proses pembelajaran yang baik banyak tergantung pada kemampuan profesional guru yang 
bersangkutan, sebab bagaimanapun baiknya dan canggihnya teori dan teknologi pengajaran tanpa kemampuan dan kemauan guru dalam melaksanakannya tidak akan mungkin diperoleh hasil yang diharapkan. Hasil pembelajaran yang optimal dapat tercapai manakala guru dapat memperbaiki kinerjanya dalam pengelolaan pembelajaran yang berujung pada peningkatan hasil belajar siswa, sehingga guru perlu kreatif, selalu berfikir dan mencari strategi pembelajaran yang menyenangkan dan lebih baik (Rahmatullah \& Inanna, 2019).

Keheterogenan siswa tersebut kadangkala penyebab kesulitan bagi guru untuk mengelolah kelas dan bahkan dalam memilih strategi mengajar yang tepat. Akhirnya guru tidak lagi melaksanakan atau mengadakan persiapan mengajar di kelas sehingga proses Pembelajaran kurang menghasilkan pengetahuan, keterampilan dan sikap siswa sesuai dengan yang diharapkan, dalam tujuan mengajar.

Berdasarkan dari wawancara peneliti terhadap beberapa guru pada mata pelajaran IPS di beberapa sekolah yang menerapkan Kurikulum 2013, guru mengakui bahwa pada saat ia mengajar banyak kesulitan yang dialami, seperti penggunaan kurikulum, struktur materi, sarana dan prasarana di sekolah yg belum mendukung, serta alokasi waktu sehingga guru sulit dalam menentukan model pembelajaran apa yang akan digunakan dan model pembelajaran apa yang sesuai dengan materi yang akan diajarkan.

Selain kesulitan tersebut, masih banyak kesulitan lain yang sering dialami oleh guru dalam proses pembelajaran. Kesulitan tersebut antara lain adalah faktor sarana dan kelengkapan proses pembelajaran seperti sarana laboratorium dan kelengkapan alatnya, buku pelajaran dan sarana ruang kelas.

Sebagai gambaran dapat dikemukakan bahwa, seorang guru kemungkinan besar sulit merealisasikan tuntutan kurikulum yang mengharuskan pelaksanaan praktikum jika kelangkapan sarana tidak ada.

Dari latar belakang yang telah dikemukakan di atas penulis tertarik untuk melakukan suatu penelitian tentang faktor kesulitan guru dalam pembelajaran ditinjau dari penggunaan kurikulum, struktur materi, sarana dan prasarana, serta alokasi waktu .

\section{METODE PENELITIAN}

Penelitian ini dilakukan bertujuan untuk "Mengetahui gambaran tentang factor kesulitan yang dialami oleh guru dan langkah-langkah yang ditempuh untuk mengatasi kesulitan yang dihadapi dalam proses pembelajaran".

Pendekatan penelitian yang peneliti gunakan metode deskriptif dengan pendekatan kualitatif. Jenis penelitian ini adalah penelitian deskriptif yang bersifat observasi tentang kesulitan-kesulitan apa saja yang dialami oleh guru dalam melaksanakan kegiatan proses Pembelajaran dan langkah-langkah yang ditempuh untuk mengatasi kesulitan yang dihadapi dalam proses Pembelajaran.

Adapun teknik pengumpulan data yang dilakukan dalam penelitian adalah; digunakan angket terbuka sebagai sumber data primer. Sedangkan observasi dilakukan untuk mencari sumber data pelengkap dari data angket. Angket tersebut diedarkan kepada responden sebagai objek yang akan diteliti, dengan maksud untuk mendapatkan berbagai data yang diperlukan. Observasi yaitu mengamati secara langsung dari beberapa komponen yang sangat diperlukan terjadap objek yang akan diteliti.

Analisis data dalam penelitian ini dilakukan selama dan sesudah pengumpulan data. Data yang terkumpul dianalisis dengan menggunakan statistik deskriptif, untuk memperoleh gambaran tentang faktor kesulitan dalam melaksanakan proses Pembelajaran. Temuan jenis hambatan dan masalah yang dialami oleh guru dari hasil analisis data dikemukakan untuk setiap sekolah dan kemudian diambil kesimpulan secara umum.

\section{HASIL DAN PEMBAHASAN}

Berdasarkan hasil penelitian disajikan data berdasarkan urutan-urutan pertanyaan dalam angket sebagai berikut:

1. Dari 10 orang guru yang menjadi responden 5 orang guru atau $50 \%$ yang masih menyatakan pelaksanaan kurikulum kurang baik, dan 5 responden lainnya yang menyatakan bahwa pelaksanaan kurikulum pembelajaran sudah baik (tepat).

2. Untuk struktur materi pembelajaran diperoleh bahwa dari 10 responden yang memberikan jawaban masing-masing 3 responden atau 30\% menyatakan bahwa struktur materi yang ada dalam kurikulum masih belum sesuai dengan tingkatan kemampuan siswa, 2 responden atau 20\% yang menyatakan bahwa materi yang telah tercantum sudah sesuai dengan tingkat kemampuan siswa. 2 responden atau 20\% yang menyatakan bahwa struktur materi yang ada belum sesuai dengan tingkat kemampuan siswa. 2 responden yang 
menyatakan bahwa struktur materi belum sesuai dengan tingkat kemampuan siswa dan satu responden atau 10\% menyatakan bahwa kemampuan siswa tergantung pada minat belajar siswa itu sendiri.

3. Untuk sarana dan prasarana diperoleh bahwa dari 10 responden yang memberikan jawaban rata-rata menjawab sarana dan prasarana sangat penting dalam mendukung proses Pembelajaran namun masih ada kendalanya. Menemui kondisi sarana dan prasarana yang ada di sekolah masingmasing. 3 responden atau $20 \%$ yang menyatakan bahwa kondisi sarana dan prasarana yang ada disekolahnya masih sangat kurang, baik perpustakaan maupun laboratorium. 1 responden atau 10\% yang menyatakan tidak ada perpustakaan, 4 responden atau $40 \%$ yang menyatakan bahwa kondisi sarana dan prasarana yang ada disekolahnya (perpustakaan) kondisinya masih baik cuma bukunya tidak pernah bertambah. 2 responden atau 20\% yang menyatakan bahwa ada perpustakaan tetapi kurang difungsikan.

4. Untuk alokasi waktu diperoleh bahwa dari 10 responden yang memberikan jawaban tentang waktu yang tersedia untuk menyelesaikan target kurikulum. Masingmasing menyatakan belum cukup dengan alasan tertentu yaitu 5 responden atau 50\% yang menyatakan kurang karena materinya luas khusunya kelas 1 dan kelas 2. 3 responden atau $30 \%$ yang menyatakan bahwa untuk mencapai daya serap sangat cukup dan 2 responden atau 20\% yang menyatakan bahwa waktu yang tersedia belum cukup karena kebanyakan memerlukan penjelasan secara menarik.

5. Untuk mengatasi kendala-kendala tersebut diperoleh saran-saran untuk menyediakan mutu pembelajaran yang lebih baik sebagai berikut:

- Sarana prasarana sekolah seperti gedung sekolah, perpustakaan dan laboratorium dilengkapi sehingga proses Pembelajaran berjalan dengan baik.

- Hendaknya MGMP dan PGRI dilibatkan untuk membahas masalah - masalah yang ditemukan/ terjadi dilapangan.

- Agar diterbitkan buku paket yang lengkap dan ditambah terus ke sekolahsekolah.

- Waktu yang disediakan dalam pengembangan materi pelajaran persentasenya dengan pembelajaran konsep yang diajarkan.

Pelaksanaan kurikulum untuk kegiatan proses Pembelajaran yang dilaksanakan selama ini masih merupakan hambatan bagi guru mata pelajaran. Masih ada guru yang belum mampu merumuskan Kompetensi Dasar (KD) sesuai yang diharapkan oleh kurikulum itu sendiri. Ini disebabkan apa yang dituntut oleh kurikulum, terkadang tidak bisa diaplikasikan dilapangan, artinya untuk membuat KD kita harus menyesuaikan dengan kondisi sekolah masingmasing. Hal ini dibuktikan dengan masih tingginya persentase guru yang menyatakan bahwa penggunaan kurikulum masih kurang baik atau sekitar 50\% dan sebagainya sudah menyatakan bahwa penggunaan kurikulum sudah sangat baik.

Hasil angket nomor 2 menyatakan bahwa struktur materi yang ada dalam kurikulum pembelajaran di sekolah masih merupakan hambatan bagi guru karena materi yang ada dalam kurikulum tersebut masih belum sesuai dengan tingkat kemampuan siswa atau ada sekitar (40\%). Karena struktur materi yang ada dalam kurikulum sudah menuntut untuk melaksanakan sesuatu metode tertentu. Dimana terkadang siswa dituntut untuk benar, tetapi kenyataannya siswa tidak mampu untuk melakukannya.

Sarana dan prasarana merupakan hal yang penting bagi guru dalam proses Pembelajaran, yang harus ditunjang dengan kelengkapan buku paket. Masih merupakan kesulitan yang berarti bagi guru jika kondisi sarana dan prasarana yang ada di sekolah masing-masing sudah tidak memungkinkan untuk digunakan terbukti dari angket nomor 3, bahwa kondisi sarana dan prasana di sekolah kurang baik atau ada sebesar (20\%) responden yang menyatakan dimana gedung sekolah maupun perpustakaan. Ada juga yang menyatakan bahwa sarana dan prasarana sudah sebagian rusak dan buku paket tidak pernah bertambah atau ada sekitar (30\%) responden. Ada juga yang menyatakan bahwa kondisi sarana dan prasarana yang ada disekolahnya masih baik atau sekitar (30\%) responden yang menyatakan dan yang lainnya menyatakan bahwa sarana dan prasarana yang ada kurang difungsikan karena membutuhkan waktu yang banyak yakni sekitar (10\%) reseponden yang menyatakan hal ini. Dengan situasi seperti di atas sejumlah tuntutan dalam kurikulum tidak tercapai jika guru tidak kreatif dalam membuat model pembelajaran sesuai yang dituntut. Karena dengan tersedianya sarana dan 
prasarana belajar berarti menuntut guru, siswa, dalam menggunakannya.

Waktu yang tersedia juga merupakan kesulitan bagi guru. Dari hasil angket nomor 4 menunjukkan bahwa ada $60 \%$ guru mata pelajaran menyatakan bahwa alokasi yang disediakan belum cukup. Ini disebabkan karena dalam kurikulum waktu yang ada hanya ditentukan secara keseluruhan. Dengan memperhatikan setiap konsep yang diajarkan dalam alokasi waktu yang tesedia dalam setiap catur wulan, maka bahan-bahan yang diajarkan tidak selesai, sehingga guru dalam mengatasi hal tersebut harus mengadakan remedial. Guru dalam mengatasi hal tersebut terkadang mengadakan remedial.

\section{SIMPULAN DAN SARAN Simpulan}

Berdasarkan hasil dan pembahasan penelitian yang telah dilakanakan diambil kesimpulan sebagai berikut :

1. Bahwa pada umumnya hambatan-hambatan yang dialami sehingga guru dalam melakukan proses Pembelajaran terdiri dari beberapa faktor yaitu, masih sulitnya guru merumuskan Kompetensi Dasar (KD) dalam mata pelajaran.

2. Struktur materi yang ada di Kurikulum masih ada yang belum sesuai dengan tingkat kemampuan siswa.

3. Alokasi waktu yang tersedia dalam proses Pembelajaran belum mencukupi dalam setiap semester.

4. Begitu pula sarana dan prasarana yang merupakan pendukung dalam proses Pembelajaran masih sangat kurang memadai khususnya di daerah.

\section{Saran}

Adapun saran berdasarkan kesimpulan sebagai berikut :

1. Hendaknya pemerintah dalam hal ini Kementerian Pendidikan dan Kebudayaan mengupayakan pengadaan sarana dan prasarana pembelajaran yang memadai terutama buku paket di sekolah.

2. Pemerintah dalam hal ini Kementerian Pendidikan dan Kebudayaan hendaknya mengadakan workshop atau pelatihan tentang pembelajaran yang baik sesuai dengan kebutuhan kurikulum, terutama bagi guru-guru yang bertugas di daerah.

3. Agar guru mata pelajaran khususnya yang mengajar di sekolah yang ada di daerah terpencil dapat menjadikan hasil penelitian ini sebagai pertimbangan untuk lebih meningkatkan kualitas proses Pembelajaran.

4. Sekolah dan Dinas Pendidikan perlu membatasi perlu membatasi siswa dalam setiap rombel Agar jumlah yang ada dalam satu rombel maksimal 30 orang siswa.

\section{DAFTAR RUJUKAN}

Ali, H, Muh., (2007). Guru dalam proses Pembelajaran. Jakarta: Cetakan Ke Tiga. Sinar Baru Algesindo.

Djamarah, Syariful, Bahri, (2000). Guru dan anak didik dalam interaksi edukatif. Jakarta: Rineka Cipta.

Hamalik, Oemar. (2008). Manajemen Pengembangan Kurikulum. Bandung: PT Remaja Rosdakarya.

Hamalik, Oemar. (2013). Dasar-Dasar Pengembangan Kurikulum. Bandung: PT Remaja Rosdakarya

Hasan, Hamid S. (2008). Evaluasi Kurikulum. Bandung: PT Remaja Rosdakarya.

Hasibuan, J.J. (20060. Proses Pembelajaran. Bandung: Remaja Rosdakarya.

Inanna, I., Rahmatullah, R., Haeruddin, M. I. M., \& Marhawati, M. (2020). Silk weaving as a cultural heritage in the informal entrepreneurship education perspective. Journal of Entrepreneurship Education, 23(1), 1-11.

Rahmatullah. (2018). Pembelajaran Ekonomi Berjatidiri Bangsa. JEKPEND: Jurnal Ekonomi Dan Pendidikan, 1(1), 10-16. https://doi.org/10.26858/jekpend.v1i1.5055

Rahmatullah, \& Inanna. (2017). Ekonomi Berkarakter Eco-Culture Sebagai Suplemen Pembelajaran Ekonomi di Sekolah Menengah Atas (1st ed.). Makassar: Badan Penerbit Universitas Negeri Makassar.

Rahmatullah, \& Inanna. (2018). Strategi Belajar Mengajar. Badan Penerbit UNM.

Rahmatullah, \& Inanna. (2019). Pelatihan Penulisan Penelitian Tindakan Kelas Bagi Guru. Jurnal Dedikasi Masyarakat, 3(1), 19-25.

Ramli, A., Rahmatullah, Inanna, \& Dangnga, T. (2018). Peran Media Dalam Meningkatkan Efektivitas Belajar. Lembaga Pengabdian 
Kadariah, Kusmaladewi, Hasmiah, Faktor Kesulitan Guru dalam Proses Pembelajaran... $\mid 20$

Kepada Masyarakat Universitas Negeri Makassar, 5-7. Retrieved from

https://oj s.unm.ac.id/semnaslpm/article/do wnload/7649/4429\%0A

Slameto. (2010). Belajar dan faktor-faktor yang mempengaruhinya. Salatiga: Edisi Revisi, Rineka Cipta.
Sudjana. (2005). Metode statistik, Edisi keenam. Bandung : Tarsito.

Usman, Moh. Uzer, dan lilis Setiawati. (2003). Upaya optimalisasi kegiatan

Pembelajaran. Bandung : Edisi Revisi, PT. Remaja Rosdakarya. 